\title{
UV-Induced Chromosome Aberrations, Sister- Chromatid Exchanges and Cell Survival in Cultured Lymphocytes from Malnourished Children
}

\author{
P. BALAKRISHNA MURTHY, ${ }^{(19)}$ M. ABDUL RAHIMAN AND P. G. TULPULE \\ National Institute of Nutrition, Indian Council of Medical Research, Jamai-Osmania (PO) Hyderabad-500007, A.P. \\ and Department of Biosciences, Mangalore University, Mangalagangotri, Konaje, Mangalore- \\ 574 152, D.K. India [M.A.R.]
}

\begin{abstract}
Summary
Cultured lymphocytes from children with kwashiorkor and from normal children were examined for their susceptibility to ultraviolet (UV)-induced chromosome aberrations, sister-chromatid exchanges and cell survival. Cells from kwashiorkor exhibited increased chromosome aberrations, but not sister-chromatid exchanges, when exposed to higher doses of UV. Furthermore, when cells from these patients were exposed to higher doses of $U V$, there was a significant reduction in viability. These results indicate that, as compared to normals, cells from kwashiorkor were more sensitive to the lethal effects of UV.
\end{abstract}

Cytogenetic studies in protein-energy malnutrition (PEM) bave revealed increased frequencies of chromosome aberrations $(2,4$, $6,15)$ and sister-chromatid exchanges (SCEs) (8). Careful controlled studies in experimental animals have suggested further that protein deficiency per se does elevate chromosome aberration rate $(13,16)$ and SCEs (9). It is of interest to study whether cells from PEM with such high "spontaneous" chromosomal lesions are more susceptible to chromosomal damage induced by mutagens and carcinogens. A study was, therefore, undertaken to examine chromosome aberrations, SCEs, and cell viability in cultured lymphocytes from kwashiorkor, a severe form of PEM, when exposed to ultraviolet (UV) light.

\section{MATERIALS AND METHODS}

Patients. Six children suffering from kwashiorkor and five normal healthy children were investigated. All the children were aged between 1-3 years, included both sexes, and conformed to descriptions given earlier (8).

Irradiation. Irradiation was done with the help of a Hanovia lamp emitting UV light of wavelength predominantly $254 \mathrm{~nm}$. Lymphocytes in whole blood were exposed to $0.5,1.0,1.5,2.0,5.0$ and $10.0 \mathrm{~J} / \mathrm{m}^{2}$ of $\mathrm{UV}$ in petri dishes.

Cell-cultures. Blood samples were collected after informed consent. Lymphocytes in whole blood were cultured in RPMI-1640 medium, supplemented with $10 \%$ heat-inactivated fetal calf serum, $100 \mathrm{U}$ penicillin $/ \mathrm{ml}$ and $100 / \mu \mathrm{g}$ streptomycin/ml, $2 \mathrm{mM} \mathrm{L-gluta-}$ mine and $1 \%$ phytohemagglutinin (Wellcome Beckenham, England) $(90 \mu \mathrm{g} / \mathrm{ml}$ culture medium). Bromodeoxyuridine (BUdr) at a final concentration of $10 / \mu$ moles $(3 \mu \mathrm{g} / \mathrm{ml})$ was added to all the cultures for $52 \mathrm{~h}$ in control and UV-treated normal and kwashiorkor cells and incubated in the dark at $37^{\circ} \mathrm{C}$. Colchicine $(0.05$ $\mu \mathrm{g} / \mathrm{ml}$ ) was added during the last $2 \mathrm{~h}$ of incubation. Metaphase preparations were made after hypotonic $(0.075 \mathrm{M} \mathrm{KCl})$ and fixative (methanol and acetic acid) treatment, as described previously (7). Slides were stained with aceto-orcein and structural aberrations were classified according to the method of Savage (14). The presence of BUdr in culture, at the concentration used, did not significantly enhance the frequency of chromosome aberrations in either UV-treated or untreated kwashiorkor and normal cultures than it's absence. For analysis of SCEs, chromosome preparations were stained with the method of Hoechst-Giemsa (12).

Cell survival. Cell survival was assessed using Trypan Blue dye exclusion test. The criteria described by Han et al. (5) were used to count viable and dead cells.

\section{RESULTS}

Cell survival. Survival rates for the UV-treated normal and kwashiorkor cultures are shown in Table 1. The results indicate that at lower doses of UV, the survival values were not different; however, with $5 \mathrm{~J} / \mathrm{m}^{2}$ and $10 \mathrm{~J} / \mathrm{m}^{2}$ of $\mathrm{UV}$, more than $50 \%$ of the cells were killed in kwashiorkor cultures as against a value of only $20 \%$ in normal cells.

Chromosome aberrations. Data on the frequencies of chromosome aberrations are presented in Table 1. The "spontaneous" chromosome aberrations in cells from kwashiorkor were significantly higher than those in the normal cells. The commonly seen aberrations in cells from kwashiorkor were gaps, chromatid breaks, and dicentrics.

Lower doses of UV resulted in only a marginal increase in the frequencies of chromosome aberrations in cells from kwashiorkor as compared to normals; however, with $5 \mathrm{~J} / \mathrm{m}^{2}$ and $10 \mathrm{~J} / \mathrm{m}^{2}$ of $\mathrm{UV}$, a pronounced increase in aberration rates was observed in cells from these patients over the control levels. (significantly different at $P<0.001$ ).

SCEs. The results of SCEs experiment are presented in Table 1. It can be seen that the mean baseline SCE frequency in cells from kwashiorkor was significantly higher than in the normal cells.

UV treatment resulted in a dose-dependent increase in the yield of SCEs, the extent of which, however, was not significantly different between normals and kwashiorkor. At higher doses of UV, second division metaphases were rarer in kwashiorkor cultures.

\section{DISCUSSION}

It has long been known that experimental animals with severe malnutrition are increasingly susceptible to tumor production when exposed to mutagens and carcinogens (3). Such unusual "whole animal" sensitivity to environmental mutagens may indicate cellular defects at the chromosomal level (1). Because chromosomes from PEM have high residual levels of chromosome damage in the form of chromosome aberrations $(2,4,6,13,15$, 
Table 1. Chromosome aberrations, SCEs and cell survival in normals and kwashiorkor

\begin{tabular}{|c|c|c|c|c|c|c|}
\hline \multirow[b]{2}{*}{$\begin{array}{l}\text { Uv dose } \\
\mathrm{J} / \mathrm{m}^{2}\end{array}$} & \multicolumn{3}{|c|}{ Normals $(5)^{1}$} & \multicolumn{3}{|c|}{ Kwashiorkor (6) } \\
\hline & $\begin{array}{c}\mathrm{SCE} / \mathrm{cell}^{2} \\
\text { mean } \pm \mathrm{S} . \mathrm{E} .\end{array}$ & $\begin{array}{c}\text { No. of aberrations/ } \\
\text { cell }^{3} \\
\text { mean } \pm \text { S.E. }\end{array}$ & $\begin{array}{l}\% \text { viable cells } \\
\text { mean } \pm \text { S.E. }\end{array}$ & $\begin{array}{c}\text { SCE/cell } \\
\text { mean } \pm S . E .\end{array}$ & $\begin{array}{l}\text { No. of aberrations/cell } \\
\text { mean } \pm \text { S.E. }\end{array}$ & $\begin{array}{l}\% \text { viable cells } \\
\text { mean } \pm \text { S.E. }\end{array}$ \\
\hline 0 & $6.7 \pm 0.32$ & $0.02 \pm 0.0085$ & $99.8 \pm 0.82$ & $8.0 \pm 0.41^{6}$ & $0.06 \pm 0.0074^{7}$ & $99.6 \pm 0.51$ \\
\hline 0.5 & $9.8 \pm 0.25$ & $0.05 \pm 0.0064$ & $99.0 \pm 0.91$ & $10.1 \pm 0.29$ & $0.09 \pm 0.0174$ & $99.2 \pm 0.72$ \\
\hline 1.0 & $11.9 \pm 0.42$ & $0.11 \pm 0.0209$ & $93.5 \pm 1.24$ & $12.6 \pm 0.54$ & $0.14 \pm 0.0017$ & $90.5 \pm 1.45$ \\
\hline 1.5 & $17.5 \pm 0.39$ & $0.13 \pm 0.0245$ & $90.4 \pm 1.92$ & $18.0 \pm 0.47$ & $0.17 \pm 0.0194$ & $89.5 \pm 2.05$ \\
\hline 2.0 & $20.4 \pm 0.50$ & $0.17 \pm 0.0094$ & $87.6 \pm 1.92$ & $21.6 \pm 0.42$ & $0.21 \pm 0.0176$ & $86.4 \pm 1.76$ \\
\hline 5.0 & $25.6 \pm 0.74$ & $0.21 \pm 0.0430$ & $81.4 \pm 3.52$ & $24.8 \pm 1.21^{4}$ & $0.31 \pm 0.0255^{8}$ & $53.5 \pm 2.42^{8}$ \\
\hline 10.0 & $31.7 \pm 0.85$ & $0.27 \pm 0.0472$ & $77.0 \pm 2.02$ & 5 & $0.39 \pm 0.0410^{8}$ & $45.4 \pm 1.25^{8}$ \\
\hline
\end{tabular}

${ }^{1}$ Values in parenthesis indicate the number of subjects studied.

${ }^{2} 25$ second-division cells were scored per subject, unless otherwise stated.

${ }^{3}$ At least 100 cells were scored per subject. Aberrations scored include both chromatid-type and chromosome-type. Classification was made as described by Savage (14).

${ }^{4}$ Based on three cells only.

${ }^{5}$ No second-division cells.

${ }^{6}$ Significantly different from controls; $p<0.05$ by Student's $t$-test.

${ }^{7}$ Significantly different from controls; $p<0.01$ by Student's $t$-test.

${ }^{8}$ Significantly different from controls; $p<0.001$ by Student's $t$-test.

16) and SCEs $(8,9)$, a study on the behaviour of these chromosomes when exposed to UV a well known physical mutagen, becomes meaningful.

Cells from kwashiorkor exhibited significantly higher background chromosome aberrations. A similar result was evident in some published data $(2,4,6,15)$. Similarly, the baseline SCEs levels were higher in cells from these patients as reported in our previous study (8). This, however, is in contrast to the data of Mutchinick et al. (11) who found no difference in SCE frequency between normals and malnourished children. Our finding of a consistent, marginal yet significant increase in SCEs in cells from kwashiorkor was evident in all our experiments and in all our repeat studies on the same kwashiorkor children.

UV-induced chromosome aberrations were more common in cells from kwashiorkor, particularly at higher doses of UV. This was associated with a marked reduction in the number of viable cells. In addition, second-division cells were rarer in kwashiorkor cultures with $5 \mathrm{~J} / \mathrm{m}^{2}$ and $10 \mathrm{~J} / \mathrm{m}^{2}$ of $\mathrm{UV}$. This may suggest that cells from kwashiorkor with increased UV-induced chromosome aberrations do not survive and thus cannot enter into the next celldivision under high doses of UV.

Increased incidence of UV-induced chromosome aberrations in cells from kwashiorkor was not associated with a rise in the frequencies of SCEs. This supports the idea that the underlying mechanisms of origin of chromosome aberration and SCEs are different (17).

Increased frequencies of chromosome aberrations in UV-treated kwashiorkor cells reported here, may not be due to a defective DNA repair, because our own study (10) of UV-induced unscheduled DNA synthesis in lymphocytes from kwashiorkor has suggested that these calls are efficient in repairing UV-induced lesions. Further studies on induced mutagenesis and DNA repair in pure isolated lymphocytes and fibroblasts from children with kwashiorkor would be warranted.

\section{REFERENCES AND NOTES}

1. Arlett, C. F. and Lehmann, A. R.: Human disorders showing increased sensitivity to the induction of genetic damage. Ann. Rev. Genet., 12: 95 (1978).

2. Armendares, S., Salmanca, F., and Frenk, S.: Chromosomal abnormalities in severe protein-calorie malnutrition. Nature, 232: 271 (1971).

3. Gori, G. B.: Dietary and nutritional implications in the multifactorial etiology of certain prevalent human cancers. Cancer, 43: 2151 (1979).

4. Gupta, R.. Gupta, M., and Ramdeo, J.: Chromosomal abnormalities in protein calorie malnutrition. Am. J. Clin. Nutr., 30: 1974 (1977).

5. Han, T., Pauly, J. L., and Minowada, J.: In vitro preferential effect of irradiation on cultured T lymphoid cell line. Clin. Exp. Immunol., 17: 445 (1974).

6. Khouri, F. P. and McLaren, D. S.: Cytogenetic studies in protein calorie malnutrition. Am. J. Hum. Genet., 25: 465 (1973).

7. Murthy, P. B. K. and Prema, K.: Sister-chromatid exchanges in oral contraceptive users. Mutation Res., 68: 149 (1979).

8. Murthy, P. B. K. Bhaskaram, P., and Srikantia, S. G.: Sister chromatid exchanges in protein-energy malnutrition. Hum. Genet., 55: 405 (1980).

9. Murthy, P. B. K. and Srikantia, S. G.: SCE frequency in malnourished mice. Metabolism, 30: 1 (1981).

10. Murthy, P. B. K. and Bhaskaram, P.: Unscheduled DNA synthesis in lymphocytes from malnourished children. Nutr. Rep. Int., 23: 321 (1981).

11 Mutchinick, O., Lisker, R., Ruz, L., Salmanca, F., and Armendares, S.: Frequency of sister chromatid exchanges in severe protein calorie malnutrition. Ann. Genet., 22: 129 (1979).

12. Perry, P. and Wolff, S.: New Giemsa method for differential staining of sister chromatids. Nature, 251: 156 (1974).

13. Sadasivan, G. and Raghuram, T. C.: Chromosomal aberrations in malnutrition. Lancet, 2: 574 (1973).

14. Savage, J. R. K.: Classification and relationship of induced chromosomal structural changes. J. Med. Genet., 12: 103 (1975).

15. Tolani, M. K., Bagchi, M., Bajpai, P. C., and Wakhlu, 1.: Chromosomal studies in protien calorie malnutrition. Indian Pediatr., 15: 569 (1978).

16. Vijayalaxmi,: Chromosomal aberrations in malnutrition. Metabolism, 24: 1415 (1975).

17. Wolff, S.: Sister chromatid exchange. Ann. Rev. Genet., 11: 183 (1977).

18. The authors gratefully acknowledge the clinical help of Dr. P. Bhaskaram.

19. Requests for reprints should be addressed to: P. B. K. Murthy, National Institute of Nutrition, Indian Council of Medical Research, Jamai-Osmania (PO) Hyderabad-500 007, A.P. India.

20. Received for publication May 8, 1981.

21. Accepted for publication February 11, 1982. 